

\title{
KECERDASAN EMOSIONAL, KONTEKS DAN PENDEKATAN BELAJAR TERHADAP BERPIKIR REFLEKTIF DAN PRESTASI AKADEMIK
}

\author{
(Kajian Terhadap Mahasiswa Akuntansi)
}

Ia Kurnia

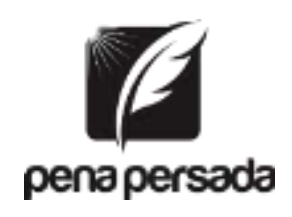

PENERBIT CV. PENA PERSADA 


\title{
KECERDASAN EMOSIONAL, KONTEKS DAN \\ PENDEKATAN BELAJAR TERHADAP BERPIKIR REFLEKTIF \\ DAN PRESTASI AKADEMIK \\ (Kajian Terhadap Mahasiswa Akuntansi)
}

\author{
Penulis: \\ Ia Kurnia \\ ISBN : 978-623-315-630-1 \\ Editor: \\ Tri Hidayati \\ Design Cover : \\ Retnani Nur Briliant \\ Layout : \\ Dita Nurul Aviqoh \\ Penerbit CV. Pena Persada \\ Redaksi : \\ Jawa Tengah \\ Email : penerbit.penapersada@gmail.com \\ Anggota IKAPI \\ All right reserved \\ Cetakan pertama : 2021
}

Jl. Gerilya No. 292 Purwokerto Selatan, Kab. Banyumas

Website : penapersada.com Phone : (0281) 7771388

Hak Cipta dilindungi oleh undang-undang. Dilarang memperbanyak karya tulis ini dalam bentuk apapun tanpa izin penerbit 


\section{KATA PENGANTAR}

Puji syukur saya panjatkan kepada Allah Subhanahu Wataa'la, karena atas berkat dan rahmat-Nya, saya dapat menyelesaikan buku ini. Penulisan buku merupakan buah karya dari pemikiran penulis yang diberi judul "Kecerdasan Emosional, Konteks dan Pendekatan Belajar Terhadap Berpikir Reflektif dan Prestasi Akademik (Kajian Terhadap Mahasiswa Akuntansi)". Saya menyadari bahwa tanpa bantuan dan bimbingan dari berbagai pihak sangatlah sulit bagi saya untuk menyelesaikan karya ini. Oleh karena itu, saya mengucapkan banyak terima kasih pada semua pihak yang telah membantu penyusunan buku ini. Sehingga buku ini bisa hadir di hadapan pembaca.

Kajian dalam buku ini bertujuan untuk untuk mengetahui relasi antara emotional intelligence, learning context, learning approaches, reflective thinking, dan academic performance. Dalam kajian ini dikembangkan relasi antara lima variabel atau konsep, yaitu variabel academic performance (pestasi akademik), emotional intelligence (kecerdasan emosional), reflective thinking (berpikir reflektif), learning approaches (pendekatan belajar), dan learning context (konteks belajar). Hasil kajian terhadap relasi kelima variabel tersebut diharapkan dapat memberikan kontribusi positif baik secara praktis ataupun teori, juga untuk penelitian-penelitian selanjutnya. Secara praktis kegunaan kajian tentang academic performance akan memberikan komparasi data perkembangan capaian prestasi akademik mahasiswa yang sangat berguna bagi pelaku pendidikan tinggi (pengambil kebijakan akademik dan dosen).

Hasil kajian tentang learning context dan learning approaches akan memberikan panduan dalam pengembangan strategi pengajaran kearah peningkatan kualitas pembelajaran dan hasil pembelajaran. Hasil kajian tentang learning context misalnya merupakan masukan bagi evaluasi aktivitas pada tingkat program studi, tingkat fakultas ataupun perguruan tinggi terutama pelaksanaan proses pengajaran yang berlangsung yang dipersepsikan mahasiswa. Hasil kajian mengenai learning 
approaches, memberikan gambaran kecenderungan mahasiswa mengenai motivasi dan strateginya dalam mengorganisasi aktivitas proses belajarnya selama mengikuti perkuliahan yang diprogramkan, sehingga bisa dijadikan bahan panduan dalam perancangan program dan strategi pendidikan. Demikian juga hasil kajian tentang reflective thinking dan emotional intelligence akan memberikan informasi perkembangan dan tingkatan cara berpikir mahasiswa, juga sikap dan emosinya. Sehingga perguruan tinggi, tingkat fakultas atau prodi juga dosen bisa mengebangkan program pengajaran dan lingkungan belajar yang mendukung perkembangan cara berpikir, sikap dan emosi yang mengarah kepada peningkatan kualitas dan hasil belajarnya. Secara teoritis hasil kajian ini dapat berkontribusi terhadap pengembangan teori pendidikan terutama pendidikan ilmu-ilmu sosial yang berhubungan dengan proses belajar mengajar dan hasil belajar.

Penulis menyadari bahwa buku ini masih jauh dari kesempurnaan. Oleh karena itu kritik dan saran yang membangun sangat dibutuhkan guna penyempurnaan buku ini. Akhir kata saya berharap Tuhan Yang Maha Esa berkenan membalas segala kebaikan semua pihak yang telah membantu. Semoga buku ini akan membawa manfaat bagi pengembangan ilmu pendidikan. 


\section{DAFTAR ISI}

KATA PENGANTAR …...............................................................ii

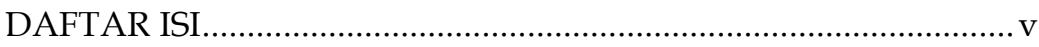

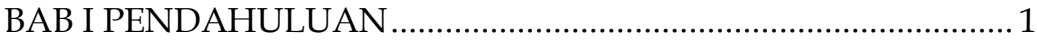

A. Tantangan Pengajaran Akuntansi di Perguruan Tinggi .......... 1

B. Pentingnya Prestasi Belajar ...................................................... 4

C. Faktor-faktor yang Mempengaruhi Prestasi Belajar............... 12

BAB II KONSEP BERFIKIR DAN BELAJAR …………………........ 19

A. Konsep Reflective Thinking (Berpikir Reflektif)....................... 19

B. Konsep Academic Performance (Prestasi Akademik) ................ 24

C. Konsep Learning Approaches (Pendekatan Belajar) .................. 26

D. Konsep Learning Context (Konteks Belajar) ............................. 32

E. Konsep Emotional Intelligennce (Kecerdasan Emosional) ........33

BAB III PERAN PENDIDIKAN ILMU PENGETAHUAN SOSIAL (PIPS) DALAM MENGEMBANGKAN KEMAMPUAN BERPIKIR INTELEKTUAL, KECERDASAN EMOSIONAL, DAN

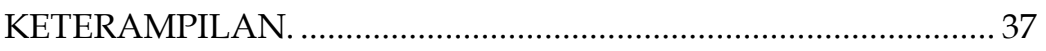

A. Konsep Dasar Ilmu-ilmu Sosial............................................... 37

B. PIPS dan Pengembangan Kemampuan Berpikir Intelektual, Kecerdasan Emosional dan Keterampilan. .................................... 41

BAB IV DESKRIPSI PRESTASI, KECERDASAN EMOSIONAL, BERFIKIR REFLEKTIF SERTA PENDEKATAN DAN KONTEKS

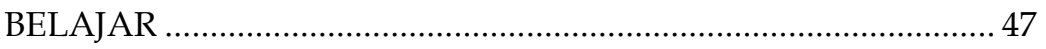

A. Deskripsi Academic Performance (Prestasi Akademik) ............ 47

B. Deskripsi Emotional Intelligence (Kecerdasan Emosional) ...... 57 
C. Deskripsi Reflective Thinking (Berpikir Reflektif)

D. Deskripsi variabel learning approaches (pendekatan belajar) .66

E. Deskripsi Learning Context (Konteks Belajar)

BAB $\mathrm{V}$ PENGARUH KECERDASAN EMOSIONAL, PENDEKATAN DAN KONTEKS BELAJAR TERHADAP BERPIKIR REFLEKTIF DAN PRESTASI.......................................71

A. Pengaruh Emotional Intelligence dan Learning Context Terhadap Deep Approache............................................................71

B. Pengaruh Emotional Intelligence, Deep Approaches, dan Reflective Thinking Terhadap Academic Performance................81

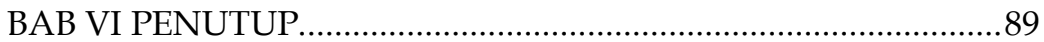

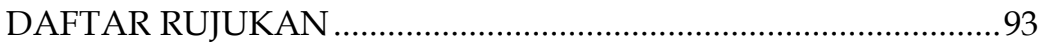




\section{BAB I \\ PENDAHULUAN}

\section{A. Tantangan Pengajaran Akuntansi di Perguruan Tinggi}

Pengajaran akuntansi pada tingkat pendidikan tinggi dihadapkan pada berbagai tantangan sebagai dampak perkembangan globalisasi ekonomi dan teknologi informasi. Globalisasi ekonomi mengakibatkan semakin menguatnya interrelasi dan interaksi antar entitas bisnis tingkat domestik dan bahkan internasional. Demikian juga, penggunaan teknologi informasi menjadi suatu keharusan bagi entitas bisnis untuk meningkatkan efisiensi dan efektivitas bisnisnya.

Perubahan yang cepat dalam lingkungan ekonomi bisnis telah menuntut tambahan atau bahkan persyaratan kemampuan/keahlian yang baru pada berbagai bidang profesi. Tuntutan tersebut diperlukan agar entitas bisnis bisa cepat beradaptasi dengan eskalasi perubahan lingkungan sehingga mampu bersaing dengan entitas bisnis yang lain serta berkemampuan melanjutkan bisnisnya sesuai harapan stakeholder.

Tuntutan standar global atas kualitas jasa dan barang sebagai dampak perubahan lingkungan ekonomi, para profesional harus memiliki pengetahuan dan kemampuan dengan kualifikasi internasional disamping kebutuhan lokal. Terbentuk dan tumbuhnya kerjasama dan kesepakatan regional dan multinasional di berbagai kawasan menambah pentingnya peran para profesional tersebut. Nayebzadeh, dkk. (2011, hlm 1), menyebutkan bahwa:

In the present time the accounting profession has faced two main challenges. The first challenge is the change and spread of the accounting role which has caused increasing demand for the skilled and professional graduates and the second one is related to existence of a gap between the current skills and the desired skills among the graduates of accounting field.

Akuntansi sebagai suatu disiplin ilmu yang merupakan bagian dari ilmu sosial memegang peranan penting dalam 
pengelolaan suatu entitas bisnis dalam dinamika perubahan lingkungan ekonomi tersebut. Akuntansi menghasilkan suatu sistem informasi keuangan suatu entitas yang sangat penting sebagai sumber data dalam pengambilan keputusan ekonomi.

Dengan demikian Akuntan sebagai Profesi bidang akuntansi dihadapkan pada kenyataan perubahan lingkungan ekonomi tersebut. Dinamika tersebut bisa menjadi peluang sekaligus ancaman. Menjadi peluang karena akan semakin banyak permintaan terhadap jasa profesi akuntan, menjadi ancaman jika tidak mampu bersaing dengan para ahli dari luar negeri dengan profesi yang sama. Tuntutan terhadap profesi akuntan semakin kuat karena tekanan yang kuat dari berbagai sumber yang meliputi: (a) globalization, (b) advances in technology, (c) business complexity, (d) societal changes, and (e) the expansion of stakeholder groups, including regulators and supervisory bodies and the broader community (IFAC, 2009).

Albrecht dan Sack (2000, hlm. 43-44) menegaskan bahwa mahasiswa sekarang harus memiliki keterampilan dan talenta yang diperlukan pasar masa depan, harus mau belajar dengan berbagai upaya untuk memperoleh keterampilan baru. Dijelaskannya pula, bahwa pendidikan akuntansi memiliki sejumlah permasalahan yang meliputi: kurikulum dan konten mata kuliah, pedagogi, pengembangan keterampilan, teknologi, sistem pengembangan fakultas, dan arah strategi. Sistem pendidikan akuntansi seringkali minim kreatifitas karena tidak mampu mengembangkan kemampuaan belajar mahasiswa. Sejalan dengan itu, Glass dan Oakley (2003, hlm. 679) berpendapat bahwa "Accounting education is failing to meet the needs of the profession by focusing curricula on memorization or accounting rules rather than the development of conceptual and analytical skills necessary for today's accounting environment".

Pendidikan tinggi pengelola pendidikan akuntansi sebagai pemasok utama profesional akuntansi dan tenaga pendidik (guru dan dosen) akuntansi, mempunyai kewajiban menghasilkan lulusan yang memiliki kemampuan dan keahlian yang diperlukan oleh stakeholder serta mampu beradaptasi 
dengan dinamika lingkungan ekonomi yang terus berubah. Dengan demikian, kurikulum, sarana dan prasarana, metode pengajaran harus diarahkan kepada kemampuan para lulusannya yang memiliki kompetensi yang diperlukan. Kompetensi tersebut harus dimiliki oleh para lulusan sehingga mampu memecahkan masalah sekarang dan kemungkinan permasalahan yang tidak biasa karena perubahan lingkungan yang sangat cepat di masa datang. Seperti yang diungkapkan oleh Turner (2011, hlm. i) bahwa "Higher education in accounting faces a challenge to shift its emphasis from reproducing technical knowledge to developing personal capabilities such as critical thinking, creative thinking, problem-solving, communication and teamwork".

Bahkan pada tahun 1999, American Institute of Certified Public Accountant (AICPA) telah merinci kerangka kerja kompetensi inti (core competence) untuk bidang profesi akuntansi seperti ditunjukkan di bawah. Selain kompetensi utama tersebut, Wahida, dkk. (2011, hlm. 5) menjelaskan bahwa seorang ahli akuntansi membutuhkan intellectual skill seperti pemecahan masalah dan pemikiran kritis.

\section{A Core Competency Framework for Entry} into the Accounting Profession

1 Cultivates growth in personal conduct and capabilities

2 Diagnoses the need for change and takes appropriate action to gain competencies

3 Measures oneself against evolving standards and meets or exceeds those standards

4 Accepts professional development as long-life process Performs reliably under changing demands

5 Evaluates information in a manner free of distortions, personal bias or conflict of interest

6 Recognizes situations where professional ethical standards apply and behaves accordingly

7 Conducts oneself with honesty Respects Confidentiality 
Commits to quality and efficlency

8 Manages stress and adapts to unusual demands with composure

9 Objectively considers others professional criticism or evaluation

10 Adheres to a level of personal appearance appropriate to the environment

11 Identifies and prioritizes career and personai goals and is accountable/learns from mistakes

Sumber : AICPA, 1999

Intellectual skill mencakup kemampuan menghubungkan konsep yang telah dipelajari dengan situasi baru, kemandirian berpikir, bersikap kritis terhadap situasi dan akses informasi, kemampuan mengaplikasikan pengetahuannya dalam berbagai konteks masalah di tempat kerja.

Tuntutan kompetensi tersebut telah memicu pendidikan tinggi meningkatkan kualitas proses belajar mengajarnya. Studi dan riset dilakukan dalam berbagai aspek yang terkait dengan kualitas tersebut mencakup metode pengajaran, kurikulum, evaluasi, sarana-prasaran dan lain-lain. Sistem evaluasi misalnya, memegang peranan penting dalam pencapaian tuntutan kompetensi lulusan yang telah ditetapkan. Dengan demikian sistem evaluasi yang baik harus menghasilkan ukuran yang mencerminkan tingkat kompetensi sesuai standar tuntutan keahlian atau profesi yang akan diampunya.

\section{B. Pentingnya Prestasi Belajar}

Prestasi akademik merupakan hasil belajar mahasiswa selama mengikuti perkuliahan berdasarkan evaluasi yang diselenggarakan secara periodik dan kontinyu. Menyimak Caplin's Dictionary of Psychology (dalam Parveen, 2014, hlm. 35): " academic achievement has been defined as the level of attainment of proficiency in academic work as evaluated by teacher or through standardized achievement tests". Lebih jelas Klobal dan Musek (dalam Baadjies, 2008, hlm. 3) menjelaskan: "Academic achievement indicates the numerical score of a student's knowledge. It measures the degree of a student's adaptation to schoolwork and to the 
educational system". Juga Howcroft (1991, hlm. 111) mengemukakan: "academic achievement in terms of the actual mark or score obtained in an examination or a test".

Prestasi akademik yang baik mencerminkan akumulasi kemampuan mahasiswa atau para lulusan dalam penguasaan kompetensi sesuai tuntutan profesinya, sehingga prestasi akademik merupakan ukuran kesuksesan seseorang dalam melaksanakan studinya di tingkat universitas atau pendidikan tinggi. Perkembangan pembangunan ekonomi sosial suatu negara berhubungan langsung dengan prestasi akademik peserta didik di negara tersebut, Ali, dkk. (dalam Mustahaq dan Khan, hlm. 17) menngemukakan bahwa: "The students performance (academic achievement) plays an important role in producing the best quality graduates who will become great leader and manpower for the country thus responsible for the country's economic and social development". Demikian juga, Coetzee (2011, hlm.13) menjelaskan bahwa: "Academic achievement is an important factor in national education because it can be seen as an indicator of whether the education in a country is successful or not".

Ukuran atau indikator prestasi akademik pada pendidikan tinggi adalah indek prestasi kumulatif (IPK). IPK merupakan nilai rata-rata yang diperoleh mahasiswa setelah mengikuti perkuliahan beberapa semester. Pentingnya IPK sebagai indikator pengukur pestasi akademik misalnya terdapat banyak perusahaan (swasta dan negeri) mensyaratkan batas minimal perolehan IPK dalam penerimaan karyawannya, batas minimal perolehan IPK juga menjadi persyaratan melanjutkan pendididikan pascasarjana, demikian juga unuk memperoleh beasiswa. Mahasiswa dengan IPK yang baik/ tinggi diharapkan menjadi seorang profesional yang lebih baik, atau kalau melanjutkan studi diharapkan mampu menyelesaikannya dengan lebih baik. Oleh karena itu, Mushtaq dan Khan (2012, hlm. 17) menegaskan bahwa banyak para peneliti menggunakan GPA (Grade Performance Academic) atau IPK untuk mengukur prestasi akademik mahasiswa pada semester tertentu. 
Tabel di bawah ini memperlihatkan IPK rata-rata yang diperoleh mahasiswa program studi akuntansi (S-1) pada beberapa universitas swasta di kota Bandung. Tidak ada data IPK pada semester genap tahun akademik 2014-2015, karena pada saat pengumpulan data, perkuliahan semester genap masih berlangsung.

Rata-rata Indeks Prestasi Kumulatif (IPK) Mahasiswa Program Studi Akuntansi (S-1) Pada Universitas Swasta di Kota Bandung

\begin{tabular}{|l|c|c|c|c|}
\hline \multirow{2}{*}{ Nama Universitas } & \multicolumn{2}{|c|}{ Tahun Akademik 2013-2014 } & \multicolumn{2}{c|}{ Tahun Akademik 2014-2015 } \\
\cline { 2 - 5 } & $\begin{array}{c}\text { Semester } \\
\text { Gasal }\end{array}$ & $\begin{array}{c}\text { Semester } \\
\text { Genap }\end{array}$ & $\begin{array}{c}\text { Semester } \\
\text { Gasal }\end{array}$ & $\begin{array}{c}\text { Semester } \\
\text { Genap }\end{array}$ \\
\hline Universitas Pasundan (Unpas) & 2,92 & 2,82 & 2,96 & - \\
Universitas Langlangbuana (Unla) & 3,09 & 3,08 & 2,86 & - \\
Universitas Islam Bandung (Unisba) & 2,86 & 3,01 & 2,44 & - \\
Universitas Winayamukti (Unwin) & 2,63 & 2,52 & 2,59 & - \\
Universitas Komputer Indonesia (Unikom) & 3,27 & 3,27 & 2,99 & - \\
Universitas Widyatama & 2,87 & 3,03 & 2,84 & - \\
Universitas Islam Nusantara (Uninus) & 3,10 & 2,85 & 2,74 & - \\
Universitas Katolik Parahyangan (Unpar) & 2,59 & 2,63 & 2,57 & - \\
Universitas Bandung Raya (Unbar) & 2,60 & 3,01 & 3,02 & - \\
Universitas Kristen Maranatha & 3,04 & 3,12 & 2,85 & - \\
Universitas Nasional Pasim & 2,55 & 2,70 & 2,85 & - \\
\hline
\end{tabular}

Sumber: Diolah dari Kopertis Wilayah IV Jabar dan Banten

Tabel di atas memperlihatkan bahwa perolehan rata-rata IPK mahasiswa pada umumnya kurang dari 3,00. Terdapat beberapa universitas dengan perolehan IPK rata-rata di atas 3,00, namun IPK tersebut paling tinggi sebesar 3,27. Kemudian, jika dilihat progres IPK rata-rata pada tiap semesternya, maka kecenderungannya IPK rata-rata tersebut mengalami penurunan. Gambaran lebih jelas tentang perkembangan ratarata IPK tersebut dapat dilihat pada gambar 1 dalam bentuk diagram batang. 


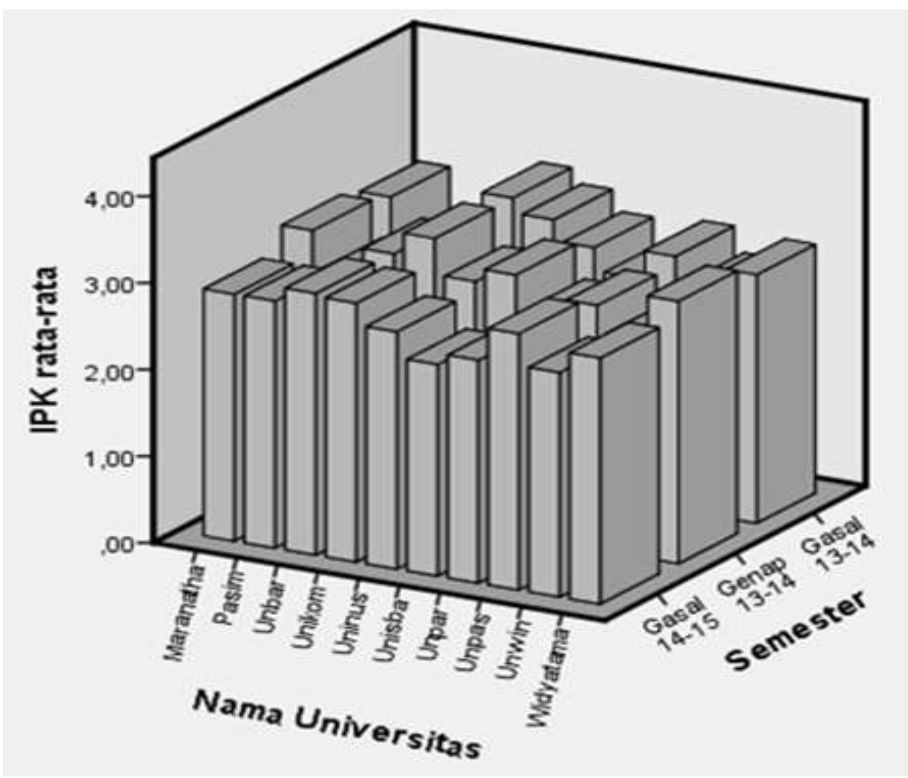

\section{Gambar 1.: Diagram Batang (Bar) Rata-rata IPK Mahasiswa Program Studi Akuntansi S-1}

Sumber: Diolah dari Kopertis Wilayah IV Jabar dan Banten

Masih rendahnya perolehan IPK tersebut merupakan permasalaham bagi pendidikan tinggi. Jika IPK merupakan ukuran ketercapaian kompetensi sesuai standar yang ditetapkan, maka rendahnya IPK menunjukkan masih rendahnya ketercapaian kompetensi tersebut. Rendahnya IPK juga menunjukkan belum efektifnya proses perkuliahan/ pembelajaran yang sedang dilaksanakan.

Survey pendahuluan dilakukan untuk mengetahui perolehan IPK, pendapat dan sikapnya terhadap perolehan IPK serta kepuasan mahasiswa secara umum terhadap program perkuliahan yang diikutinya. Sampel mahasiswa dipilih secara random dan diperoleh 58 orang mahasiswa dari semester empat dan enam pada salah satu universitas swasta di kota Bandung. Komposisi responden tergambarkan pada data di bawah. 
Komposisi Responden Survey Pendahuluan

\begin{tabular}{|l|r|r|r|}
\hline \multicolumn{1}{|c|}{ Smtr/Jk } & \multicolumn{1}{|c|}{ Pria } & \multicolumn{1}{c|}{ Wanita } & \multicolumn{1}{c|}{ Total } \\
\hline Semester 4 & 7 & 18 & 25 \\
\hline Semester 6 & 12 & 21 & 33 \\
\hline Total & 19 & 39 & 58 \\
\hline
\end{tabular}

Sumber: Pengolahan data survey pendahuluan

Statistik deskriptif perolehan IPK responden hasil survey pendahuluan tergambar pada data di bawah ini.

Statistik Deskriptif IPK Responden Survey Pendahuluan

\begin{tabular}{|l|l|l|r|}
\hline \multirow{4}{*}{ IPK } & Semester & Desc. & Statistic \\
\cline { 3 - 4 } & Semester 4 & Mean & 3,076 \\
& & Std. Deviation & 0,45365 \\
& & Minimum & 2,29 \\
& & Maximum & 3,81 \\
\cline { 3 - 4 } & Semester 6 & Range & 1,52 \\
\hline & & Mean & 3,0518 \\
& & Std. Deviation & 0,42164 \\
& & Minimum & 2,22 \\
& & Maximum & 3,95 \\
& & Range & 1,73 \\
\hline
\end{tabular}

Sumber : Pengolahan data survey pendahuluan

Memperhatikan data di atas, walaupun rata-rata IPK (mean) mahasiswa semester empat sebesar 3,08, simpangan baku (std. deviation) termasuk tinggi yaitu sebesar 0,453. Simpangan baku yang tinggi menunjukkan terdapatnya kesenjangan perolehan IPK antar mahasiswa, hal tersebut juga bisa dilihat dari perolehan IPK yang paling tinggi (maximum) sebesar 3,81 sedangkan yang paling rendah (minimum) sebesar 2,29. Hampir sama dengan semester empat, pada semester enam perolehan rata-rata IPK sebesar 3,05, kesenjangan perolehan IPK antar mahasiswa masih tetap tinggi. Terlihat 
juga adanya penurunan IPK mahasiswa pada semester enam jika dibandingkan semester empat.

Selanjutnya kepada responden diminta pendapatnya tentang sejauhmana usaha atau upayanya untuk memperoleh IPK tersebut, jawaban responden tergambar pada data di bawah.

Tingkatan Upaya Memperoleh IPK

\begin{tabular}{|l|r|r|r|r|}
\hline \multicolumn{1}{|c|}{ Respon } & Frequency & Percent & $\begin{array}{c}\text { Valid } \\
\text { Percent }\end{array}$ & $\begin{array}{c}\text { Cumulative } \\
\text { Percent }\end{array}$ \\
\hline Sudah maksimal & 8 & 13,8 & 13,8 & 13,8 \\
\hline Cukup maksimal & 25 & 43,1 & 43,1 & 56,9 \\
\hline Belum maksimal & 25 & 43,1 & 43,1 & 100,0 \\
\hline Total & 58 & 100,0 & 100,0 & \\
\hline
\end{tabular}

Sumber: Pengolahan data survey pendahuluan

Data di atas menunjukkan bahwa sebagian kecil responden yaitu sebanyak $13,80 \%$ merasa sudah maksimal berusaha atas IPK yang diperolehnya, sedangkan sebagian besar menyatakan cukup maksimal dan belum maksimal dengan jumlah responden yang sama yaitu sebanyak $43,10 \%$. Hal tersebut menunjukkan bahwa sangat banyak responden yaitu $86,20 \%$ tidak maksimal secara sungguh-sungguh untuk memperoh IPK yang terbaik, atau dengan kata lain sebanyak $86,20 \%$ responden masih bisa ditingkatkan lagi perolehan IPKnya. Sedangkan gambaran perbandingan tingkatan usaha perolehan IPK berdasarkan semester terlihat pada gambar 2 . 


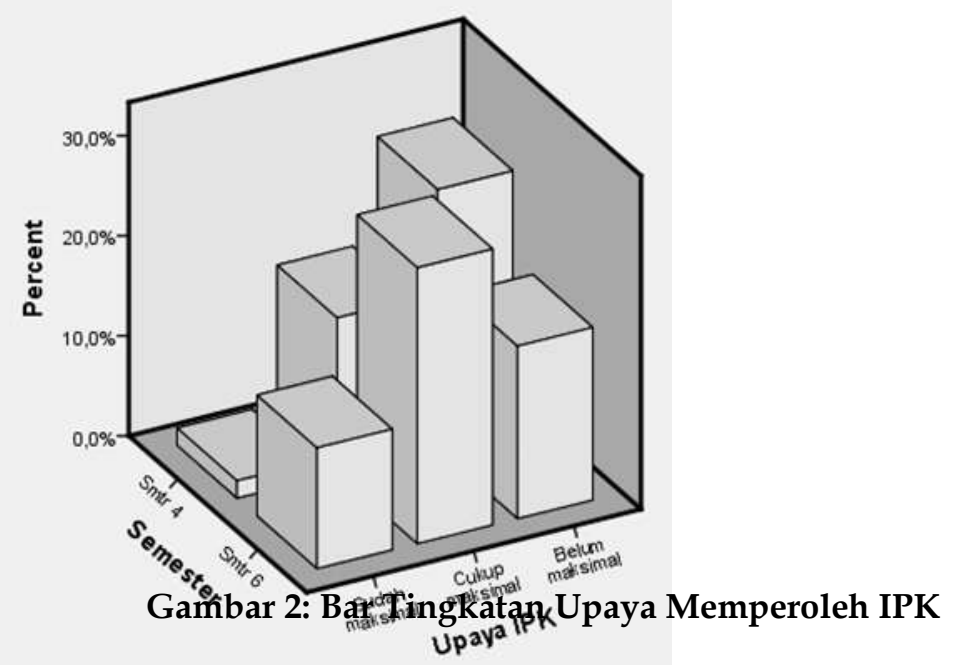

Sumber: Pengolahan data survey pendahuluan

Gambar 2 memperlihatkan, responden semester 6 lebih banyak dibanding semester 4 yang menyatakan 'cukup maksimal' dan 'sudah maksimal', sedangkan responden semester 4 lebih banyak menyatakan 'belum maksimal'. Dengan demikian mahasiswa semester 4 lebih berpeluang meningkatkan kembali perolehan IPK-nya.

Kemudian responden diminta menyatakan sikapnya terhadap pernyataan: "Secara keseluruhan, saya merasa puas dengan program dan proses perkuliahan di perguruan tinggi ini", jawaban responden terlihat data di bawah ini.

Sikap Terhadap Program Perkuliahan

\begin{tabular}{|l|r|r|r|r|}
\hline \multicolumn{1}{|c|}{ Respon } & Frequency & Percent & $\begin{array}{c}\text { Valid } \\
\text { Percent }\end{array}$ & $\begin{array}{c}\text { Cumulative } \\
\text { Percent }\end{array}$ \\
\hline Tidak Setuju & 4 & 6,9 & 6,9 & 6,9 \\
\hline Netral & 20 & 34,5 & 34,5 & 41,4 \\
\hline Setuju & 31 & 53,4 & 53,4 & 94,8 \\
\hline Sangat Setuju & 3 & 5,2 & 5,2 & 100,0 \\
\hline Total & 58 & 100,0 & 100,0 & \\
\hline
\end{tabular}

Sumber: Pengolahan data survey pendahuluan 
Data menunjukkan bahwa sebagian besar responden menyatakan "setuju" yaitu sebesar $53,40 \%$, yang bersikap netral juga cukup banyak yaitu sebesar $34,50 \%$. Secara keseluruhan bisa disimpulkan bahwa responden merasa puas dengan sistem atau program perkuliahan yang diikutinya. Hasil tersebut terlihat bertentangan jika dibandingkan dengan perolehan IPK responden yang belum optimal juga dengan tingkat kesenjangan yang tinggi.

Jika respon tentang sikap responden terhadap program perkuliahan tersebut dibandingkan berdasarkan semester, maka dapat tergambarkan seperti pada gambar 3. di bawah ini. Terlihat bahwa responden semester 6 relatif lebih banyak dibandingkan semester 4, baik yang menyatakan 'sangat setuju', ataupun bersikap netral, bahkan 'tidak setuju'.

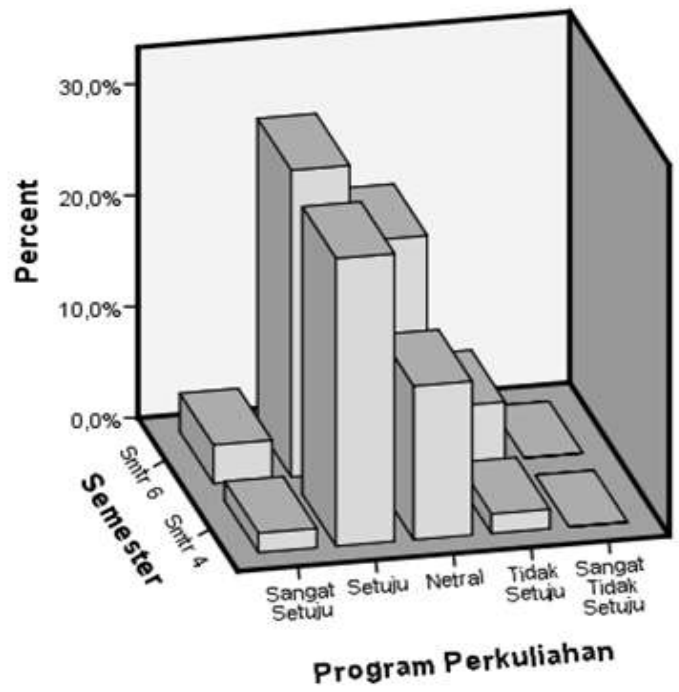

\section{Gambar 3.:Bar Respon Sikap Terhadap Program} Perkuliahan Berdasarkan Semester

Sumber: Pengolahan data survey pendahuluan 


\section{Faktor-faktor yang Mempengaruhi Prestasi Belajar}

Berdasarkan kajian terhadap data empirik dan survey pendahuluan yang diuraikan di atas, sangat menarik untuk mengkaji lebih lanjut tentang prestasi akademik, serta mengkaji faktor-faktor apa saja yang berhubungan atau yang mempengaruhi prestasi akademik tersebut terutama untuk mahasiswa akuntansi. Mengkaji faktor-faktor yang mempengaruhi prestasi akademik sangat penting bagi perguruan tinggi dan dosen sebagai umpan balik dalam meningkatkan kualitas proses belajar-mengajar (perkuliahan). Yorke (dalam Li, dkk., hlm. 3) menegakan: "A range of performance predictors have been developed in relation to course quality assurance".

Terdapat banyak kajian juga penelitian yang dilakukan untuk mengetahui faktor-faktor yang mempengaruhi pretasi akademik. Hasil kajian literatur menunjukkan beragamnya faktor yang mempengaruhi prestasi akademik, demikian juga hasil penelitian menunjukkan beragam hasil yang berbeda, termasuk kajian dan penelitian terhadap prestasi mahasiswa akuntansi. Faktor-faktor yang mempengaruhi prestasi akademik mahasiswa akuntansi tersebut berdasarkan kajian dan hasil penelitian, misalnya: prior accounting knowledge (Byrne dan Flood, 2008); age, work experience, dan mathematical aptitude (Gracia dan Jenkins, 2003); motives, expectations, dan preparednes (Arquero, dkk., 2008).

Beberapa penulis dan peneliti lain mengidentifikasi faktor-faktor yang mempengaruhi prestasi akademik meliputi: background characteristics, self perception of abilities, dan highest degree aspiration (Rasmusen, 2002; Bauer dan Liang, 2003, dalam Brown, hlm. 14-18), faktor-faktor tersebut disebutnya 'precollege characteristics'. Background characteristics meliputi: high school achievement, gender, SAT scores, ethnicity, parental education, dan parental income. McKenzie dan Schweitzer (Li, dkk., hlm. 3) mengelompokan faktor-faktor tersebut menjadi: academic, psychosocial, cognitive dan demographic categories. 
Penulis dan peneliti lain dengan pendekatan yang berbeda mengidentifikasi faktor-faktor yang mempengaruhi prestasi akademik tersebut dari sudut pandang pembelajar atau mahasiswa yaitu dari cara atau strategi belajar mahasiswa. Abraham (2006, hlm. 1) misalnya, mengaskan:

Research in accounting education has almost neglected both student perceptions of the learning context and their approaches to learning. Instead, studies have focused on either the teaching context or the outcomes of learning. This omission has meant that accounting educators often experience difficulty in understanding what students conceive learning to be, how they perceive the learning task, or how they approach learning.

Sejalan dengan pendapat Abraham, sebelumnya Gow, dkk. (1994, hlm. 118) juga menegaskan bahwa sangat penting melakukan pengujian mendalam terhadap cara mahasiswa belajar sehingga akan memberikan panduan bagaimana mahasiswa belajar sekaligus memberikan panduan terhadap strategi pengajaran yang diperlukan untuk meningkatkan kualitas pembelajarannya.

Kedua pendapat di atas, sepakat menyatakan pentingnya pemahaman terhadap pendekatan belajar (learning approaches) mahasiswa dan konteks belajar (learning context) berdasarkan persepsi mahasiswa, karena akan memberikan panduan terhadap strategi pengajaran yang harus dilaksanakan oleh dosen untuk meningkatkan kemampuan belajar dan prestasi akademiknya. Dengan demikian, penelitian tentang learning approaches sangat penting dilaksanakan baik itu oleh individu dosen secara langsung maupun oleh institusi pendidikan tinggi. Seperti yang dikemukakan oleh De Lange \& Mavondo, 2004 (dalam Byrne dan willis, 2008, hlm. 35): “Higher education (HE) research has demonstrated that improved educational outcomes are achieved when educators are better able to understand the way in which students learn". Apostolou, dkk (dalam Eskola, 2011, hlm. 12) menegaskan bahwa "Research about students should be a primary mission of accounting education research. We should be interested in how students learn". Kemudian juga, "The demand for life-long learning in a rapidly changing environment calls for 